\title{
Correction to: Dilute acid hydrolysis of microalgal biomass for bioethanol production: an accurate kinetic model of biomass solubilization, sugars hydrolysis and nitrogen/ ash balance
}

\section{Carlos Eduardo de Farias Silva ${ }^{1}$ [D Alberto Bertucco $^{1}$}

Published online: 18 May 2020

(C) Akadémiai Kiadó, Budapest, Hungary 2020

\section{Correction to: Reaction Kinetics, Mechanisms and Catalysis (2017) 122:1095-1114 https://doi.org/10.1007/s11144-017-1271-2}

The original publication of the article contained an error in Eq. 4. The correct equation has been given with this Correction.

$$
\frac{d P o l}{d t}=-k[P o l]^{n}
$$

Publisher's Note Springer Nature remains neutral with regard to jurisdictional claims in published maps and institutional affiliations.

The original article can be found online at https://doi.org/10.1007/s11144-017-1271-2.

Carlos Eduardo de Farias Silva

carloseduardo.defariassilva@studenti.unipd.it

1 Department of Industrial Engineering DII, University of Padova, Via Marzolo 9, 35131 Padua, Italy 